\title{
AZERBAIJANI LITERARY LANGUAGE OF THE 17th CENTURY: THE SOCIO-POLITICAL CONTENT AND LANGUAGE OF THE ERA
}

Abdullaeva Gizilgul Agali Gizi ${ }^{1}$

\begin{abstract}
The article reveals the sociopolitical content of the XVII century. Both dependence on foreigners and the influence of internal tensions between tribes on the political life of the Safavid state are investigated. In such historical circumstances, the cultural environment is also based on sources that have not yet been identified. Under such circumstances, a description of the language is given. In particular, during the period of the Shah Abbas (during the rule of other shahs), attitudes toward the Turkish language are expressed in contradictory ideas. It has been established that the stage of the XVII century literary language is not a way out, but history as a turning point. This is proved, on the one hand, by scientific data, as well as facts about language. As a result of the research, it turns out that the language policy that underlies the
\end{abstract}

existence of the state and the nation is carried out in the direction of Turkic rule in the 17 th century. The article contains the rich language of the real world, including the introduction of the Turkish language in the history of the 17th century Azerbaijani literary language, the decline of the Persian language (including the accompanying Arabic language), the destruction of cults, as well as the intensification of new processes, such as differentiation, stabilization and democratization examples. In the 17 th century, as in all periods of the history of the Azerbaijani literary language or at all stages of historical development, the process of defining a literary language and defining different styles (charming, scientific, official epistolary) took place. Style plays a significant role in relationships. In volume, the rate is determined in style

\footnotetext{
${ }^{1} \mathrm{PhD}$ of Philology, Associative Professor at the Department of Turkology Baku State University, Azerbaijan. Email : gizilgulabdullayeva@gmail.com. ORCID: https://orcid.org/0000-0002-1194-0001
} 
and appears. As a result, it is noted that the 17th century very dynamically develops phonetic, lexical and grammatical norms in the direction of nationalization. The development of literary language, of course, all levels of language are available. But what if you want to translate it into one language? The real fact, which is obvious, or hidden, or not, is voluminous in the volume, which is a lexical system, which leads to great changes. This does not mean that in other languages, such as the phonological system, the language is checked and the file is checked. All, that is, it is not so, but here is a breakthrough for change. This is not an idea or an idea of ignorance and ignorance, but there is no certainty that changes in language change. The truth is that everything that creates a change in the original of another phenomenon, which confirms the existence of legality. The definition of phonetic norms for a certain period of time (continent, period or phase) is contained in a volume that is one of the other publicly available versions of the phone in the language, and, in each other's eyes, by removing from onedimensional parallels, stabilization in language and content.
Keywords: Azerbaijani literary language, literary language norms, differentiation, stabilization, democratization, periods of literary language, socio-political and historical content, linguistic landscape, classical poetry genres, classical poetry, language, national language, folklore language, syllables, fairy tale, norm variability ...

\section{Introduction}

Relevance of the topic. The XVII century is an integral part of the XVII-XVIII centuries, the first half of the final stage of the Azerbaijani literary language. This is a very controversial issue, and from a socio-political point of view, this is a very tense phase. To solve the dilemma in this tense policy, to clarify the position of the Turkish language, is one of the pressing issues that are really needed. XVII-XVIII centuries are considered norms of civilization. However, the differentiation, stabilization and democratization, defined in the 17th century through self-analysis and originating from this historical stage, point to the eighteenth century and the rise of this hegemony. In the case of 
stabilization of differentiation, both processes lead to democratization, and ultimately this unifying process causes trials, and it is transmitted through the XVII century to the XVIII century, and also consolidated in this century. Given that all ages are interrelated. Thus, one cannot even speak of a complete study of the historical paths of development of our language in the study of the literary language of the seventeenth century, the historical stage of our literary language. The separation of phonetic, lexical and grammatical norms is more relevant for explaining the independence, presidency and durability of the Azerbaijani language in the light of discussions in the 17th century. It is impossible to comprehensively study literary linguistic norms without revealing the sociopolitical, historical context and language. This proves once again how relevant our to.

\section{Methods}

The Azerbaijani literary language has two historical epochs. One of them is the period of writing, which, according to the new classification of $\mathrm{T}$. Hajiyev, dates from the second century
$\mathrm{BC}$ and the VI-VII centuries BC. This era dates back to the history of our literary language as tribal consolidation. The consolidation and consolidation of the Turkic-speaking peoples leads to the creation of a people, and this means that the language of the people communicates. All this contributes to the development of the culture of writing our language. The period of writing begins with the VII century and continues to this day. Based on convincing scientific foundations and logic, T. Hajiyev's new classification, which he presents to the world of science, shows that the writing period has three phases (Hajiyev T.I.,2012). The first stage covers the VIIXII centuries. This is characterized by the historical stage at which the "Book of Dede Gorgud" was a magnificent monument. If this can be said, the period begins with the existence of the book Dada Gorgud. The basis of the national language is also derived from the book Dede Korkwood. These realistic scientific discoveries of $\mathrm{T}$. Hajiyev are due to the vocabulary fund, which is always stable and not constant. Starting from the second stage of the writing period (XIII-XVI centuries), the national language is determined. Thus, this 
definition summarizes the complete formation of our national language, which developed in the XIII century, at the end of the second stage of Fizuli. At the stage of the XVII-XVIII centuries, our national language enters a new developmental perspective. It turns out that normalization norms are based on this update. A foreign language, which includes the concept of a leading language, is Persian (also Arabic, which, despite the degradation, even if it is Arabic with the same name), has always been translated into Turkish, but this foreign language is slowly being translated into Turkish. Thus, the concept of leading language varies depending on the Turkish language. As a result, the Turkish language is decided in favor of the Turkish language, as well as the variability of the genre. At the stage of the next XIX-XX centuries, there is a change in styles, as well as fluctuations of lexico-terminological norms. It is well known that phonetic, phonetic, phonetic, phonetic, phonetic, phonetic and phonetic, which covers the norms of the literary language, reflecting the language of the previous historical stages in the final phase of the writing period (from the 30 s to the present) orthographic, orthoepic, and lexical and grammatical norms. In this regard, works are written, dictionaries are compiled, opinions and opinions are met in the media, but not confusion, the principle of unity begins, the correct orientation to regulating the complexity contained in the terminology of the language is taken as the basis. Thus, the literary language has stepped forward to its development.

It should not be forgotten that stylized styles, style, functional and structural certainty, national language, which plays a vital role in the development of literary language and most of the linguistic facts and plays a major role in this issue, and most importantly, literary the norm that constitutes the essence of the language is taken as the main factor.

\section{Results}

Each of these stages has a special role in the development of the literary language. Especially in the 17th century it is necessary to mention them. Because the XVII century is a time of intensification of new processes, indeed, it is an important milestone in the history of Azerbaijani literary language. In order to further clarify our thoughts, we can 
say that every historical period moves to the memory of history with its sociopolitical, economic, historical and cultural content, as well as the national language environment. From this point of view, XVII century is not an exception. XVII century is a component of XVII-XVIII centuries, the first half of the new stage of the national language. In all historical periods, as in the stages, the XVII century presents multidimensionalities with sociopolitical and historical content. The XVII century feudal wars, which are neighbors of the 16th century on the one hand, and on the other hand, prepare for the 18th century from various angles, as a stage of long-term internal strife after the 18th century feudal wars, attacks by foreign countries, and the death of I Shah Tahmasib (1524-1576). The Ottoman and Safavid wars between the two brothers were an example of this. Sunnis and Shia aggression, which has already won politics in strengthening these struggles, also played a leading role. II Shah Ismail (1576-1577), who came to power after Shah Tahmasib, attempted to soften the Sunnis and Shia relations, one of the foundations of the Ottoman and Safavid wars, did not bear fruit on their own, but this resulted in the creation of the Safavid opposition to the Shah. Apparently, as a result, II Shah Ismayil was killed in his mysterious appearance. The arrival of the Shah's elder brother, Mohammed Mirza Khudwain, will be instrumental in the weakening of the Sawwezi state. Thus, the Ottoman sultans, themselves using this internal weakening of the Safavid Empire, are able to occupy Azerbaijani lands in parts. Naturally, both domestic dependence and internal conflicts between tribes cause the weakness of the Safavids state. Until the reign of Shah Abbas, the territorial integrity of the Azerbaijani lands to the Ottoman Empire and the indefinite state continues. Historian $\mathrm{O}$. Afandiyev writes that "the OttomanSafavid wars are closer to the reality than to the hostility of the two brotherly Turkish people (Ottoman and Turkish Turks) as the collision of the economic and political interests of OttomanSafavid rulers" (Emmani,1983). The historian, S.Ashurbeyli, also made an appropriate comment about the Ottoman Empire's occupation of Azerbaijani lands in order to capture the commercial caravan routes of the Ottoman Turks in the territory of Azerbaijan and to free the 
Caspian Sea with the Baki port (History of Azerbaijan, 1999). For us, no matter for what purpose, it was to occupy our lands and to have our ancient and everlasting lands occupied by another. And these lands begin to be returned during the reign of Shah Abbas. This is when the power of Muhammad Hodja, who understands the complexity of the situation, begins voluntarily after his son I Shah Abbas (Bakikhanov A.A., 1987). It was a historic period that "the Ottomans had already captured all the provinces of Azerbaijan except the Ardabil, Garabagh and Talysh regions" (Gurbanov C., 2011). Naturally, "the main task of Shah Abbas in 1587 was to get rid of the destruction of a state that was exposed to foreign invaders" (History of Azerbaijan, 1999). The truth is that after Shah Abbas was proclaimed king, he first achieved concentration of internal control in his own hands and prevented internal paralysis. It was during this period that the Safavid state began to grow stronger (Gudratov D., $2000)$.

\section{Discussions}

The Azerbaijani lands occupied by the Ottoman sultans were returned by Shah Abbas (Demirli M., Mammadli M., 2000). Shah began reforms reflecting different areas. First, "I, Shah Abbas, skillfully used the contradictions between European countries and strengthened the borders of the Safavid Empire. His actions as a reformer created favorable conditions for the development of the country's economy" (Hasanaliyev Z.M., 2000). Naturally, in these areas a culture of culture existed, and language policy was the basis for the existence of the state and the nation. Demirchizade wrote in the seventeenth century: "In Azerbaijan there was Persian, Rumyr (Osmanli) in another place, Azerbaijani everywhere, Arabic was used everywhere, and even at that time there were changes" (Demirchizade A., 1978). True, this is an axiom that does not need proof that wars, bloody battles, massacres, or even small ones or at least have their negative consequences. However, as Demirchizade said, in spite of the fact that various languages function at this historical stage, as a result of intensive processes, the Azerbaijani language in these languages is characterized as a historical reality, which develops ascending line. Speaking about the 
Azerbaijani literary language of the XVII century, T. I. Hajiyev also notes that "the national literary language of Azerbaijan has entered the ascending line of life" (Hajiyev T.I., 2012). Unfortunately, there are conflicting opinions about the language policy of the 17 th century. Thus, it is time to return to this issue and exchange views on the position of the literary language of Azerbaijan in the seventeenth century. In the seventeenth century, most researchers associate all this with the policies of I Shah Abbas (particularly in language policy). Naturally, the controversial presentation of the political trends of Shah Abbas is a shadow of reality. On the one hand, the policy of codification of the king is exaggerated, and on the other hand, the policy of the Turkish language (ie, Azerbaijani) as the state language is also ignored. The policy of falsification of Shah Abbas is largely connected with the movement of the capital to one of the Iranian cities of Isfahan, as well as with particular attention to the Persian-speaking citizens of the country and their placement in various government posts. For us, this cannot be taken as the main reason. Due to the change of capitals in many countries throughout the history of any policy. "Why should I accept the Safavid state as a Persian state by transferring the capital to Isfahan by Shah Abbas, before we accept Nishapur, Ray, and then the state Isfahan as a Turkic state? Or Sultan Teymuri, Shahruh? moved the capital of his state to Herat. Did the Teymuris state come to the Afghan state after that, meaning the Turkish state? Of course not!" (Gurbanov C., 2008). The reason is that Shah Abbas moved to Isfahan to protect the capital of the Ottoman Empire from the occupation of the Ottoman Empire as a result of the occupation, and placed all state affairs there. In our opinion, along with the transfer of the capital, countless Azerbaijani families, even prominent poets and intellectuals, transfer them to Isfahan with their families the number of ethnic minorities in favor of the Turks, their position in the immediate vicinity of the Turks, the majority of Turks who use the Turks, who are the basis of diplomats sent to foreign countries who are the guarantors of negotiations in Turkish after the dinner given to foreigners visiting the state of Safavid (Mahmudov Y.M., 1980), the president of the country that built the state palace 
in Isfahan in the style of painting of the Tabriz state palace (Emmani.., 1994), this is not the kind of Persian politics on this unrealistic soil, on the contrary, it should remain in the memory of history as a propagandist of the Turkinsians national policy.

Writing poems by the name "Abbas" and "Shah Abbas" is also a sign of this reality. In addition to all of this, as it is widely reflected in our tales, I have been continuously advocating for the purpose of identifying the causes of the dissatisfaction of the people's representatives in order to get acquainted with the suffering of the people, to learn their desires and desires, evident proof.

The poem "Efendi", written in the genre of the above example, was written by Abbas in the seventeenth century. Another poem "Effendi" in the same genre tells about MP Vagife, the creator of the scene in the eighteenth century:

I do not know what happens to this mountain every day, I fell out from behind a tulip. I was lucky again that when it was time to leave, sir (Vagif M.P., 1988 ).

The first of these is the linguistic material of the XVIII century, the recovery period of healing, i. E. Time of the XVII century, and the other - the peak of healing. Consequently, one of the initial stages of healing is a linguistic environment in which the genres of folk poetry are already publicized and gained prestige. Nevertheless, the language, the style features, the state of folk poetry, the level of artistic value and the appearance of the language are ambiguous in both. This shows that the XVII century was a historical stage in which genres of folk poetry were presented, and most importantly, the Turkish language. In fact, it should be emphasized that "in the state of Safavid ... the overwhelming majority of emirs and idols who were members of the Shah's family were Turks or Turks. Of course, the state itself was" them. "And in the palace, in the army, in the correspondence, the Turkish situation remained in the 17 th century" (History of Azerbaijan, 1996). All this confirms that the activity of the" golden language" (Karimov P., 2013), which was equivalent to the Turkish language in the 17th century, continued at this historical stage. In the real sense of the word, in the 17th century, "Turkish was the official language of the Safavid palace" ( 18 . This took place in the era of 
Shah Abbas, in the period of the Shah Safi, during the second Period of Shah Abbas, and also in the later stages of our language development. II Shah Abbas, like me Shah Abbas, "entered the nation, realizing problems and difficulties of people of all classes, solved their difficulties in the court of justice and tried to improve the country. He issued decrees to heal society, and settled houses of corruption, that is, barracks, caravans, deck chairs (opium houses)" (Hasanaliyev Z., 2011). That is, during the rule of these rulers "they were Turks who built and defended the state" (Bayramli Z., 2006). Engelbert Kempfer, a German scholar who traveled to Iran between 1685 and 1694, wrote that "the Turkish language spread from the palace to the home of high-ranking and influential people, and so far the one who wants to be honored, speaks this language. It is now criminal to ignore Turkish for anyone worthy of his head. Turkish is easier than all oriental languages. Vugar and the magnificence of the Turkic-speaking style led him to the fact that he became the only spoken language in the palace and the kingdom of the heavens" (Sources of History of Azerbaijan, 1989). Before Kempfer in the Safavid era, French traveler Jan Baptiste Taverna also informs us in the $40 \mathrm{~s}-60 \mathrm{~s}$ of the 17 th century (Onullahi S.M., Hasanov A.Q., 1974).

Azerbaijani Turkish was a fact of generality in the Caucasus and even in the East. Additionally, from the beginning of the XVI century and beginning of the 17th century, introspective novelties began to function, giving them "decree" for the Turkish language as a state language. The issue of the ethnic identity of the Safavid State plays an important role in the root of all these issues. There are also facts that the Safavid State was presented as a non-Turkic state, in particular the Iranian state, despite the fact that it was a Turk state until it collapsed. Researcher Z. Bayramli very well states that the Safavids in the 17th century preserved their Turkish essence as a basis for our sincere handling of the false ideas about the transformation of Persian into the end of the sixteenth and sixteenth centuries $(10, p$. One of the main factors that proves the continuity and strengthening of the Safavids' Turkic essence is the fact that the Persian language was influenced by the more Turkish language in this historical period was compared with the 
prevalence of the Turkic language in comparison with Mongols and Seljuks (Azeroglu B., 1981). As a continuation of our ideas, the following information is further emphasized by M.Seyidov's ideas: "In the XVI-XVII centuries, Azerbaijani intellectuals were the most commonly written in their native language. This aspect also influenced even the judges. Some of them enjoyed poems written in Azerbaijani language. If not, the artists who lived in the palace did not live in the palace" (Seyidov M., 1963 ). This is a matter of particular importance and not of the researchers' attention. It should be noted that the XVII century is a middle-aged position in the neighborhood of XVI and XVIII centuries. It is a transition phase, both in politics and in the economy, as well as the transition phase of the XVII century XVIII through this historical development phase of our language. Thus, XVII century plays a transitional phase. This proves that the Azerbaijani literary language of the XVII century is traditionally developed in the background of the unity of the innovation. That is, it does not break down before itself, and it prepares its renewal in the future. Thus, while classical linguistic traditions dating from the 16th century continue to resettle in the XVII century, on the other hand, introspection changes take place, and they continue to be "continuing their own development" in the process. If it is possible to say so, the new language between the old and the new, that is, the tradition and the modernity takes on the national language. Thanks to the national language, the tradition also becomes a shareholder. New processes such as differentiation, stabilization, democratization, reorganization, and transformation make the new stage of national language a reality. In short, XVII centuries centered on the process of modernization within the language, and "literary language - the literary language of Azerbaijan in the XVII century enriched at the expense of live folk language, far away from alien influences" (Arasli H., 1956). All of this looks like a preparatory phase for the XVIII century. From this historical point of view, the Arabic language, which goes as far as the Persian language and the winged wing, breaks down, and these languages are already in the recession. This is because of the classic poetry genres that the direct Persian and Arabic 
tongue is drawn by, and the classic poetry genres, and the Arabic and Persian linguistic examples (especially non-common Arabic and Persian words) ) to the path of recession to reality.

As a result, intravenous intuition becomes a massive form of the classical book language. Thus, as a result of these new processes going on in the language, Turkish language gains a balance between Persian and Arabic, and only after this equilibrium begins the Turkish way of propaganda. Because the Turkish language presupposes, of course, the genre of folk poetry associated with syllabic, syllabic, syllabus, Turkic language units that form the basis of folk poetry genres, including Turkish-Arabic and Persian lexemes, more specifically, the generalization of common foreign lexical units will provide. It was a sedate Arabic and Persian words all over the world in the dictionary of our language (also in the vocabulary fund). Which, since the words "Dede Korkut" from the words of the 17 th century, has gained a wide range of work in all historical periods of our language, and today the vocabulary of our language and even the vocabulary collection were in the form of a dictionary. Finally, as a result of all these speeches, folklore language is embraced by the way of leadership. As we move toward the eighteenth century, this level of leadership continues to evolve over the rising line and has already gained a peak in the 18th century. Democratization does not make a difference only with folk poetry genres. There is such democratization in the allegory. It is also determined by the introduction of the livelier language elements at different levels of language and the direction of the language of the literary and artistic language written in the dialect to the simplicity. Thus, such processes as language differentiation, stabilization, democratization, reorganization of calligraphy make the Azerbaijani literary language of the XVII century a unique norm. The norm of each age is determined by the language of literary and artistic samples that emerged at that time. Let's remind, "In the XVII century Persian language literature was in deep recession. In the 16th century BC Persian-language literature was the center of IranianAzerbaijani territory. However, since the beginning of the 16th century this literature has entered the recession, the 
process of Turkish-speaking literature has begun" (Hasanaliyev Z., 2007). Naturally, such a direction of development is that in the 17 th century, a great army of command is formed. The authors of this word army, written in Turkish language by "XVII century, independent and original development of the literature of the 17th century" (Safarl A., 1992), not only mention the traditions of Fadai, Mohammed Ammani, Christi, Gavsi Tabrizi, Saib Tabrizi, Shah Abbas Kabr (I Shah Abbas), Zafar, Tazi Afshar, Sadiq bey Afshar, Vahid Kazvini, Shah Abbas Sani (Shah Abbas Shah), Makhabed Ganjavi, Movi, Majub, Mirza Saleh Tabrizi, Melik bey Avci, Vaiz Gazvini, Safi, Murtazulu Sultan Shamlu, Effect of classical poetry as well as Ashig Abbas Tufarganli, Yellow Ashig, Azizi. For a long time, these artists have been told that they are only followers of the Fuzuli literary school and can not go beyond Fuzuli. True, enough linguistic facts to confirm this are also recorded. The comparative analysis of Fuzuli's poem "Leyli and Majnun" and the poem "Warga and Gulsara" of Christ confirms the similarity of language, which coincides with one another in parallel.
275

Even in the poems of some poets, we can see the repetition of Fuzuli's expressions, thoughts, inclinations, emotions, moods. But in general, all these poets did not imitate Fuzuli as a whole, but simply regarded it as their master, teacher, and learned creatively from it. The tradition of these outstanding artists who wrote and created in various genres of classical poetry, such as Mesnevi, ghazal, qesi, kita, muhammas, muhadda, mabrabba, scribe, translator, taţbeyt, rübai, sünzâmî ... Fuzuli as well as Alisher Navai effect. True, "Fuzuli's influence was more apparent in the works of poets who wrote in classical style. But learning from Fuzuli was creative "( Safarl A., 1998). Some of those creators of classic style writing have appealed to folk poetry genres and have dual writings in their creativity. Poets such as Azizi, Sari Ashug, Ashyg Abbas Tufarganli who appealed to folk poetry in the XVII century directly influenced the development of XVII century poetry with examples of literary and artistic samples, and in addition to the classical poetry in the dual genre, the language of classical literature towards democratization they have not lost their power. The result, however, was that 
these great word makers gave birth to the ideal of literary and artistic language, and to democracy.

Thus, representatives of the XVII century, especially the artistic style, introduced the new language of the language. But they could not separate from each other. Thus, there was a transitional connection between the classical book and the folklore language. The first ones conveyed their traditional words and phrases, the general Arabic and Persian words to the latter, while the latter did not deprive them of the spirit of the spoken language. The transmitted transmissions did not allow them to break the barrier of the livelier language; they only expanded the scope of their linguistic wealth and added to their poetic power; the latter were able to present the tradition of the XVII century by combining the tradition with the live word language. In this connection, the latter were insistent on meeting, so they could properly fulfill their mission to reach the peak of the XVIII century. T.I.Hajiyev writes that "the 17 th century is sometimes called stagnation, sometimes a period of fall. It is a period of time when no one is saying that the two language styles change their position" (Hajiyev T.I., 2012). It really is. As a result of the synthesis of this place of change, these linguistic materials, which were created by these prominent personalities and transferred to the memory of history, should have laid the foundation for the definition of the 17 th century language standard. That is, fluctuations in the language led to normal variability. Because in any period of the norm it does not matter, in general it belongs to the historical category. This means that the norm is a variable. But this volatility, of course, is not systemic. That is, the variability of the norm is not a frequent process. For example, from the Hasanoglu period to the XVII century, i. E. Stability of the XIII-XVI centuries. This date is four centuries. The factors that make up the stability or variability of the norm are mainly related to the language background, gesture, genre, style. If a leading language can maintain its stability for a long time, the stability of the norm and its lifetime will expand, even if the language is predominant. Since Persian language (including Arabic), which challenged foreigners in the XIII-XVI centuries, ensured the prestige of Arabic and classical poetry, the norm reflecting 
Persian (and Arabic) language retained its stability, maintaining its stability. However, from the beginning of the 17 th century, as we have already mentioned above, the Azerbaijani language, gradually becoming the state language, is capable of turning the protection of syllable and folk poetry into reality, as we have already mentioned, with the gradual decline of foreign languages.

\section{Conclusion}

Thus, the classical norm, which demonstrates long-term activity, if you can say, "the norm financed from abroad" in the 17th century, gives its place to the "national norm" reflecting the Turkish language, syllable, and genres of folklore. In all cases, the literary-linguistic norm of the XVII century prevents the occurrence of a gap between the oral and written texts of the literary language. Thus, this new development trend in normalization leads the literary language of the 17th century to a living spoken language, which ends at the end of the 18th century. The development of the literary language in the XVII century and its peak in the XVIII century due to the expansion of the scope of the more popular genres of folk poetry. Thus, the line of development of a language is based on a folk language. As a result, new complex processes, such as differentiation, stabilization, democratization and nationalization, since the beginning of the 17th century, reached their peak in the 18th century. Thus, the fact that the norm, which reflects both the macro and microsystems in all historical periods and stages, is the first of its kind manifestation of the renewal of the Azerbaijani literary language of the XVII century.

\section{References}

Arasli H. (1956). History of the Azerbaijani literature of the XVII-XVIII century. Baku: University of Azerbaijan, , $324 \mathrm{p}$.

Ashurbeyli S. (1997).Shirvanshahs state. Baku: Azerneshr, 405 p.

History of Azerbaijan (1999). VII volume. III c.Baku: Science, 534 p.

History of Azerbaijan (from the far back to the 1870s.(1996). Baku: "Azerbaijan" 
publishing house, $872 \mathrm{p}$.

Sources of History of Azerbaijan(1989).

Baku: ADU edition, 326 p.

Azeroglu B.(1977). Mohammad

Ammani. Baku: Science, 129 p.

Azaroglu B.(1981). Saib Tabriz's art world. Baku: Writer, 175 p.

Bakikhanov A.A.(1987). GuliistaniIram. Baku: Elm.

Bayramli Z. (2015). The role of the Turkish Red Cross officers in the structure and management of the Safavid state of Azerbaijan. Baku: Europe, 348 p.

Bayramli Z.(2006). Azerbaijan Safavi State Structure and Management System, Baku: ADPU, 258 p.

Demirchizade A.(1979). History of Azerbaijani literary language. I h. Baku: Maarif, 1979, 268 p.

Demirli M.,Mammadli

M.(2000).History of Azerbaijan.Baku:Tafakkur, 472 p.
Efendiyev O.(1993). Azerbaijan

Safavid State. Baku: Azərnəşr, 300 s.

Emmani. (1983).Works (Composer A.Safarli). Baku: Writer, 339 p.

Emmani (1994). From ancient times to the twentieth century. Baku: Azerneshr, $687 \mathrm{p}$.

Fadai.(1957). Bakhtiarnama (Composer Q.Mammadli). Baku: Publishing House of Azerbaijan University, 155 p.

Hajiyev T.I.(2012). History of Azerbaijani literary language I Baku: Science, $476 \mathrm{p}$.

Hasanaliyev Z.(2007). International relations of the Safavid state in the XVII century. Baku: Nurlar, 344 p.

Hasanaliyev Z.M.(2000). Safavi state (1st half of the XVII century). Baku: "Altay" publishing house, 163 p.

Hasanaliyev Z.(2011). İnternal and foreign policy of Azerbaijan's empire state during the reign of Bayramli Z. II Shah Abbas. Baku: Science, 88 p. 
(Composer A.Safarli). Baku: Azerneshr,

Kerimov P.(2011). XVII century mother tongue Azerbaijani lyric. Baku: Nurlan, $354 \mathrm{p}$.

Karimov P.(2013). is a Turkic-speaking creator of P. Sadiq bey Sadiq. Baku: Publishing House "Science and Education", 159 p.

Gurbanov C.(2013). The ruler of Safavid I Shah Abbas (1587-1629).

Baku: Zardabi LTD, 176 p.

Gurbanov R.(2008). History of Caucasus. Baku: Zardabi LTD, 583 p.

Gudratov D.(2000). History of Turkic peoples. Baku: Umman, 496 p.

Mahmudov Y.M.(2006).Azerbaijani diplomacy. Baku:Education,416 p.

Mahmudov Y.M.(1980). Travel to the Land of Fire.Baku:Youth, 119 p.

Masihi (2012). The couch. (With his manuscript) (Composer A. Safarli). Baku: Science, 480 p.

Masihi (1977). Varga and Gülsa $288 \mathrm{p}$.

Masihi (2005). Varga and Gülsa (Composer A.Yusifli). Baku: East-West, $336 \mathrm{p}$.

Onullahi S.M., Hasanov A.Q.(1974). More than two unknown letters from the Safavid rulers (from the date of correspondence in the Azerbaijani language). // The series of scientific works, history and philosophy sciences, № 4, p. p.84-93.

The 17th-century Azerbaijani lyric (Composers P.Karimov and M.Huseyn). Baku: Nurlan, 2008, 340 p.

Seyidov M.(1963). Tabrizi. Baku: EA publication of the Soviet Union, 99 s.

Safarl A. (1992).Masihi. Baku: Youth, $232 \mathrm{p}$.

Safarli A., Yusifli X.(1998). Ancient and Medieval Azerbaijan Literature. Baku: Ozan, 632 p.

The Tabriz Plateau (2005). Divan (Designer P.Kerimov. Baku: Nurlan, , 
Periódico do Núcleo de Estudos e Pesquisas sobre Gênero e Direito

Centro de Ciências Jurídicas - Universidade Federal da Paraíba V. 9 - $\mathrm{N}^{\circ} 02$ - Ano 2020

ISSN | 2179-7137 | http://periodicos.ufpb.br/ojs2/index.php/ged/index

$449 \mathrm{p}$.

Vagif M.P.(1988). His works (compiled

by A.Dadashzade). Baku: Writer, $192 \mathrm{p}$ 